\title{
Investasi Saham pada Sektor Perbankan adalah Pilihan yang Tepat Bagi Investor di Pasar Modal
}

\author{
Vera Wydia Utami, Rayna Kartika \\ Universitas Andalas, Fakultas Ekonomi, Padang, Indonesia \\ Email korespondensi: vera.utami25@gmail.com
}

\begin{abstract}
ABSTRAK
Pada saat ini industri perbankan merupakan salah satu indeks yang diminati dipasar modal, karena sebagian besar masuk indeks favorit di daftar indeks pasar modal, perbankan memiliki indeks tersendiri yaitu indeks infobank15 disini tertera daftar 15 bank yang berkinerja terbaik, disamping itu sebagian besar di indeks lq45 diisi oleh perusahaan perbankan bebara industri perbankan beberapa bank seperti diantaranya pada artikel ini Bank central Asia, Bank Negara Indonesia, dan Bank Rakyat indonesia telah masuk indeks lq45 selama 5 tahun pada 2013 hingga tahun 2017 di selama 5 tahun perusahaan ini selama 5 tahun dinilai oleh pasar modal memiliki kinerja paling likuid dan menguasai kepitalisasi pasar terbesar selama periode, selama periode berjalan ke tiga bank terus menunjukkan kinerja yang semakin membaik, namun tepertengahan tahun 2018 terjadi inflasi nilai tukar dollar terhadap rupiah meningkat hingga Rp.15.000 per \$1 dolarnya, sehingga ke tiga bank besar ini mengalama dampak penurunan harga saham yang cukup signifikan, disamping itu ada juga bank seperti Maybank dan Permata bank yang menunjukkan kinerja yang tidak membaik hingga ke titik mengalami permasalah keuangan (Financial Dissress), apakah dengan permasalahan tersebut masih membuat industri perbankan menjadi pilihan yang tepat untuk para investor ?, Artikel ini membahas mengenai analisis literatur yang memperkuat bahwa bank masih layak dijadikan pilihan terbaik bagi para investor.
\end{abstract}

Kata Kunci: Perbankan, Indeks lq45, Inflasi, Pilihan terbaik investor

\section{PENDAHULUAN}

Pasar modal adalah roda pengerak ekonomi indonesia, investor memiliki peran yang signifikan terhadap pergerakan laju per ekonomian indonesia, pertumbuhan ekonomi nasional tidak akan jauh dari pengaruh berkembangannya pasar modal. Selama ini, pasar modal menjadi jempatan dan memfasilitasi masyarakat jika masyarakat ingin 
berinvestasi untuk memenuhi kebutuhannya, pasar modal adalah tempat bertemunya landers dan borrowers dimana pihak yang membutuhkan dana dan memiliki kelebihan bertemu dengan kata lain tempat para investor berktivitas (Fahmi, 2014).

Pada saat ini, individu maupun badan usaha dapat memperoleh dana tambahan dan memperluas jaringan usahanya dengan menyalurkan kelebihan dana yang dimilikinya untuk diinvestasikan dipasar modal sebagai investor. Pertumbuhan investor di pasar modal indonesia dinilai cukup baik, peningkatan kinerja operasional jumlah (Single Investor Identification) SID terkonsolidasi yang terdiri dari investor pemilik Saham, Surat Utang, Reksa Dana, Surat Berharga Negara (SBN) dan Efek lain yang tercatat di Kustodian Sentral Efek Indonesia (KSEI) jumlah SID sudah mencapai angka 1 juta pada pertengahan tahun 2017. Dapat dilihat dari grafik pertubuhan jumlah investor dari jumlah SID tahun 2012 - Desember 2017 :

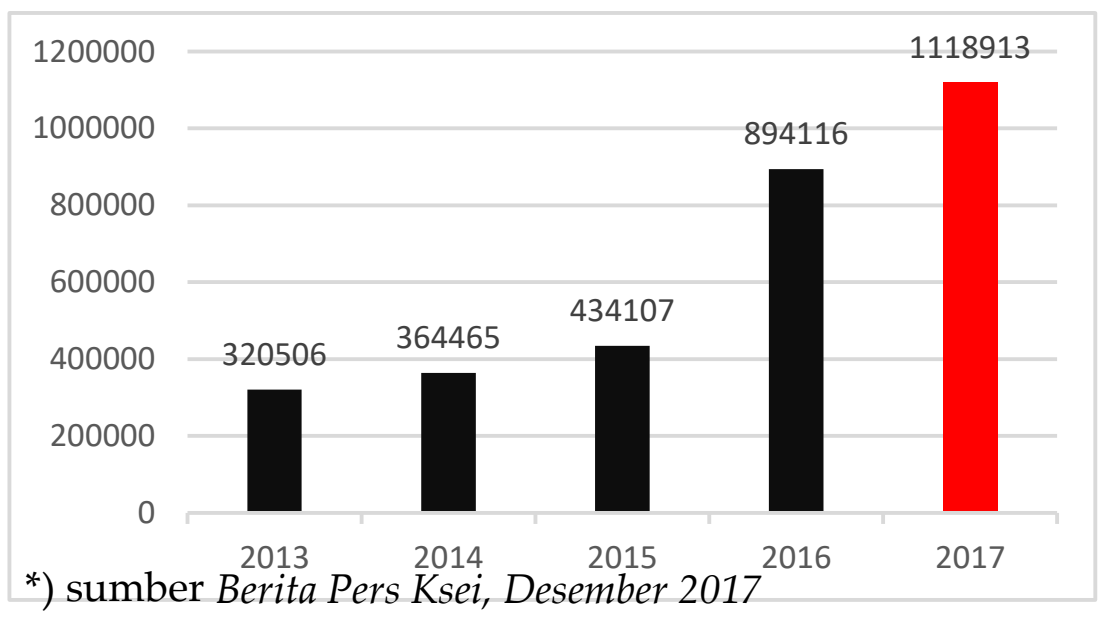

Grafik 1. Grafik Pertumbuhan Total Jumlah SID (2012-2017)

Dari sekian banyak investor di indonesia pasti mereka menginvestasikan dana yang dimilikinya di salah satu sektor industri yang menghasilkan return yang cukup besar bagi mereka karena investor memiliki ekspektasi pada return dari suatu instrumen investasi tersebut. Pemikiran ini sejalan dengan konsep bahwa individu akan menyukai utilitas yang lebih tinggi untuk dari suatu tindakan yang mereka lakukan untuk mencapai kemakmuran (Solihat \& Arnasik, 2018 dikutip oleh Aprayuda \& Misra, 2020). Berdasarkan sektor industri yang ada di pasar modal Tabel 1 menunjukkan perkembangan perdanganfan saham sectoral selama tahun 2018.

Tabel 1. Perkembangan Perdangangan Saham Sektoral Tahun 2018

\begin{tabular}{clcccc}
\hline Sektoral & \multicolumn{3}{c}{ Rata-Rata Tahun 2018 } & \multicolumn{2}{c}{ Kapitalisasi Pasar } \\
\cline { 2 - 5 } & Volume & Nilai (Rp & Freq & Nilai (Rp) & $\%$ \\
& (juta) & Miliar $)$ & (Ribu) & & \\
\hline
\end{tabular}




\begin{tabular}{lrrrrr}
\hline IHSG & \multicolumn{1}{c}{ (2.549,46 } & $9.554,69$ & 384,84 & 6.884 .880 .830 .908 .210 & 100,00 \\
Pertanian & 212,39 & 149,04 & 12,04 & 108.996 .954 .995 .864 & 1,58 \\
Pertambangan & $2.523,11$ & $1.466,79$ & 60,54 & 396.658 .240 .927 .036 & 5,76 \\
Industri Dasar & 590,77 & 620,20 & 36,80 & 570.335 .348 .380 .365 & 8,28 \\
$\begin{array}{l}\text { Aneka Industri } \\
\text { Industri }\end{array}$ & 360,04 & 427,41 & 23,16 & 368.273 .097 .563 .186 & 5,35 \\
Konsumsi & 922,90 & $1.326,28$ & 30,86 & 1.452 .559 .728 .492 .340 & 21,10 \\
$\begin{array}{l}\text { Properti \& Real } \\
\text { Estate }\end{array}$ & & & & & \\
Infrastruktur & $2.658,60$ & 978,87 & 50,43 & 421.827 .173 .655 .460 & 6,13 \\
Keuangan & & & & & \\
Perdangangan & $1.550,40$ & $1.447,42$ & 55,83 & 735.502 .072 .346 .634 & 10,68 \\
\hline
\end{tabular}

*) sumber Statistik Mingguan Pasar Modal, OJK 2017

Sebagaimana dilihat dari Tabel 1. nilai kapitalisasi pasar dari 100\% indeks harga saham gabungan, bagian dari 30\% IHSG merupakan industri sektor keuangan, yang dimana berarti sub sektor perbankan di dalamnya memiliki pengaruh yang cukup besar bagi kegiatan pasar modal. Hampir sepertiga dari total indeks harga saham gabungan di miliki oleh sektor keuangan secara tidak langsung dari 1 juta investor sebanyak 300 orang investor diindonesia memilih untuk berinvestasi di industri perbankan, semakin tinggi kapitalisasi pasar berarti nilai yang dimiliki sektor tersebut semakin baik dan sangat diminati oleh para investor.

Diketahui bahwa perbankan merupakan sektor penting dalam perekonomian. Bank memainkan peran kunci dalam penguatan dan pengembangan ekonomi, dan sektor bank juga menjadi mediator yang lebih aman antara depositors dan investors. Penting bahwa proses kinerja bank untu didefinesikan saat mereka mengelola asset kemapuan bidan industri mereka secara optimal tujuannya untuk mengembangkan kualitas bisnis (Alrgaibat, 2016).

Menurut analisi lembaga sukuritas indopremier, sektor keuangan bakal menjadi primadona di tahun 2018 karena sepanjang 2017, sektor keunagan merupakan salah satu sektor yang mengalami peningkatan yang amat tinggi, dari sisi tren banyak nilai saham-saham emiten yang mengalami penguatan dan akan terus berlanjut (Alrgaibat, 2016). Disamping itu sektor keuangan masih menjadi jawara di pasar saham hingga agustus 2017, ditengah kenaikan indeks harga saham gabungan yang hanya meningkat 8,86\%, sejak awal periode, sektor keuangan unggul lebih baik, sektor finansial terutama perbankan mencata $19,63 \%$ pada periode yang sama pada pertengahan tahun (Husni, Rahim, \& Aprayuda, 2019). berarti disini tercermin bahwa pergerakan kenaikan ataupun penurunan indeks harga saham gabungan sangat di 
pengaruhi oleh pergerakan sektor industri perbakan jika sektor perbankan mengalami rata-rata meningkat atau harga saham rata-rata menguat maka akan mempengaruhi pergerakan indeks harga saham gabungan, begitu pula sebaliknya.

Sementara itu dari periode maret hingga pertengahan tahun 2018 indonesia mengalami inflasi yang disebabkan efek rupiah yang semakin melemah pada agustus 2018, (Koesrindartoto et al., 2020) memprediksi bahwa inflasi agustus 2018 sebesar 0,05\% secara bulanan. Angka ini lebih rendah dari inflasi di bulan sebelumnya tercatat sebesar 0,28\%. Inflasi tahunan di bulan agustus 2018 diperkirakan mencapai hingga 3,31\%. Hingga oktober 2018 nilai tukar rupiah berada diatas Rp.15.000 melemah kelevel Rp.15.223 Per dollar As, mengakibatkan selama pertengahan tahun Indeks harga saham gabungan anjlok sebesar 8,75\% persen yang mengakibat kan indeks harga saham gabungan jatuh berada di bawah garis suppport level 6.000 sebesar 5.600 (Koesrindartoto et al., 2020). Gambar 2. Menunjukkan Grafik IHSG pada tahun 2018.

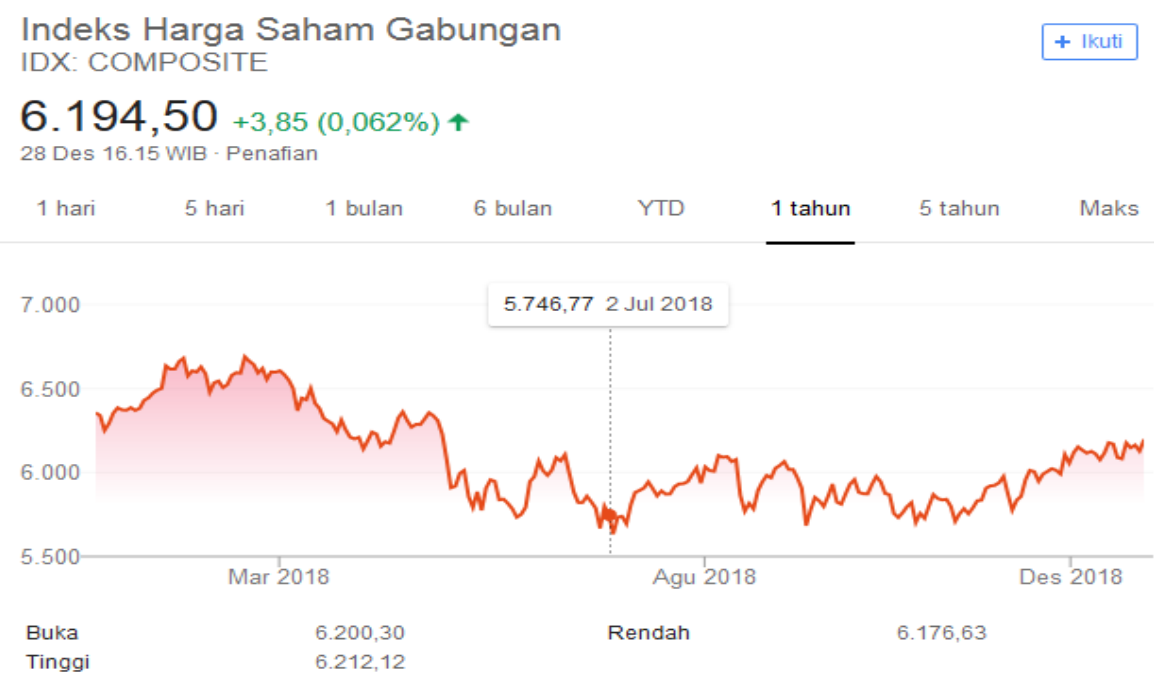

Gambar 1. Menunjukkan Grafik IHSG pada tahun 2018.

Dapat dilihat dari Ganbar 1 tren IHSG nilai tukar dolar terhadap rupiah sangat menekan fluktuasi indeks IHSG selama tahun 2018. Hal ini menunjukkan grafik penurunan dari awal tahun hingga akhir tahun tidak dapat kembali ke harga normal seperti periode sebelum maret, pengaruh dari pelemahan nilai rupiah sangat berpengaruh terhadap nilai harga saham di pasar modal. Dari kondisi ini industri perbankan harus memperkuat lini bisnisnya, dan berhati-hati terhadap pelemahan nilai tukar rupiah terhadap dolar terutama bagi bank yang menyalulrkan kredit dalam bentuk valuta asing karena ini akan berpengaruh kepada bank devisa yang menyalurkan kredit ke nilai dolar karena sumber pembayaran dalam bentuk rupih 
(Hidayati, 2014). Selain itu, beberapa analisis kondisi rupiah terus melemah punya potensi resiko langsung dan tak langsung pada sektor perbankan ini. Efeknya secara langsung datang dari kewajiban utang yang mendominasi nilai valuta asing yang dimilik pihak bank. Sementara itu secara tidak langsung datang dari nasabah atau debitur yang memiliki kegiatan usaha pada pendekatan impor.

Disini indonesia memiliki suatu tantangan global yang harus dihadapi karena harga komoditas dunia cendrung mengalami penurunan harga komoditas, tetapi secara keseluruhan pertumbuhan global cukup membaik, karena terjadinya perang dagang Cina dan AS yang belum cukup ingin bekerja sama dan terjadi perlambatan ekonomi di tionkok. Disisi domestik, perekonomian indonesia kedepan dihadapkan pada tantangan berupa empat permasalahan struktural domestik dengan pandangan pada arah membangun perekonomian nasional. Terkait dengan fundamental perekonomian indonesia, tantangan lainnya pada sektor keuangan kususnya perbankan masih belum mendukung kegiatan yang bersifat jangka panjang. Sektor keuagan indonesia masih di dominasi oleh sektor perbankan sektor perbankan orientasinya masih dari sumber jangka pendek, sehingga memiliko resiko mismatch atau tidak cocok dengan keadaan real perekonomian indonesia (Handayani, 2017).

Sebagai salah satu penggerak ekonomi pasar modal memiliki fungsi strategis yang menarik perhatian banyak pihak maupun lembaga-lembaga lain, tidak hanya pihak yang membutuhkan dana (Borrwrs) dan pihak yang ingin meminjamkan dana (Landers), tetapi pemerintah juga termasuk didalamnya. Disemua negara tepatnya diindonesia menaruh perhatian yang lebih besar terhadap pasar modal karena beberapa peran strategis yang dimilikinya untuk memperkuat kekuatan ekonomi di negara tersebut. (Untung, 2011; Aprayuda \& Misra, 2020) menyebutkan pada dasarnya terdapat empat item yang berperan penting bagaimana pasar modal menjadi pengerak disuatu perekonomian suatu negara, yakni : 1. sebagai Sumber dihimpunya dana, 2. Sebagai alternatif investasi Para yang memiliki modal (emiten) dan Investor, 3. Penghimpun dana modal di pasar modal cenrung relatif cukup rendah 4. Pasar Modal Akan cukup memberikan dorongan terhadap perkembangan investasi.

Saat ini instrumen investasi yang sangat terkenal dan paling diminati dipasar modal adalah saham, perusahaan menerbitkan saham sebagai caranya untuk mendapat tambahan dana dari pemodal atau masyarakat. Investor individu maupun kelompok yang tertarik atau menyukai perusahaan tersebut lalu pemodal tersebut dapat mempercayakan dana yang dimilikinya kepada dengan cara membeli saham yang diterbitkan. Sebagai imbalan atas hasil menempatkan dananya tersebut, investor 
akan mendapatkan bukti kepemilikan yang dimiliki berupa saham pada perusahaan tersebut (Hidayat, 2010). Selain itu, investor kalangan muda juga ikut terlibat berinvestasi di pasar modal, investor muda menilai berinvestasi di pasar modal adalah hal yang positif dan bisa mendapatkan keuntungan bagi mereka (Aprayuda \& Misra, 2020).

Dalam jenisnya efisiensi dipasar modal dibedakan menjadi 3 tingkatan, 1 Pasar efisien bentuk lemah (Weakform), 2 Pasar Bentuk setengah kuat (Semi Strong), 3 Pasar efisien bentuk kuat (Stong Form) Pada penelitian (Mulyaningtyas, 2017) yang mebguji tingkat efisiensi pasar modal di indonesia bahwa bursa efek indonesia berada ditingkat semi-kuat (semi strong) hasil penelitiannya mengungkapkan kandungan informasi yang disajikan memiliki inisiasi dividen yang positif dengan tingkat signifikansi sebesar 6\% di Event date, dan ada tingkat kecepatan dari penyesuaian reaksi pasar terhadap pengumuman pembagian dividen 1 hari, ke hari satu tanggal kejadian. Penelitiannya didukung dengan modal biaya agensi dan teori signaling, ditunjukkan dari tingginya tingkat biaya agensi dan tingkat ke asimetrisan informasi. Hal ini sesuai dengan keadaan sesungguhnya kondisi paling ideal dengan adalah kondisi yang menunjukkan nilai Semi-Kuat. Selain itu, investor individu paling banyak bereaksi pada berita internet faktor disebabkan karena kurangnya pengetahuan investor dan terlalu percaya diri dengan informasi jangka pendek informasi yang terkandung di dalam media internet (Sofyan, Putra, \& Aprayuda, 2020).

Isu politik dan nilai Kurs sangat berpengaruh terhadap keadaan pasar modal seperti yang tejadi pada tahun 2018 terungkap pada penelitian (Liwe, 2018) yang mengungkapkan reaksi investor dalam pasar modal atas peristiwa menguat nya kurs dolar amerikat seirkat terhadap nilai tukar rupiah dengan kesimpulan nilai penguatan kurs dolar AS terhadap rupiah memberikan pengaruh signifikan terhadap (Abnormal Return) dan adanya perbedaan Trading Volume Activity yaitu perbedaan aktivitas volume antara sebelum dan sesudah kejadian saat peristiwa menguatnya kurs dolar Amerika serikat terhadap Nilai tukar rupiah. Untuk kinerja perbankan sendiri pada penelitian (Veno, 2017) dengan hasil untuk tren kinerja perbankan tahun 2008-2014 cendrung meningkat dilihat dari segi profitabilitan keuangan ROE dengan angka tertinggi di tahun 2009, Tren kenerja keuangan di prediksi akan terus meningkat hingga akhir tahun 2017.

\section{METODOLOGI}




\section{Populasi dan Sampel}

Data IDX menunjukkan bahwa subsektor perbankan memiliki 81 industri yang telah listing dipasar modal indosnesia, untuk populasi sebanyak 81 perusahaan, untuk artikel diwakili dengan 5 perusahaan diantaranya:

1. Bank Central Asia (BBCA)

2. Bank Rakyat Indonesia (BBRI)

3. Bank Negara Indonesia (BBNI)

4. Bank MayBank (Maya)

5. Bank Permata (BNLI)

Disini penulisi sekaligus membandingkan dari segi BUKU (Bank Umum Kegiatan Usaha) antara bank yang memiliki modal inti kategori 4 diatas $>=$ Rp30 triliun diatrannya BBCA-BBRI dan BBNI dengan bank yang memiliki nilai modal inti kategori 3 Rp.5 Triliun-Rp.30 Triliun. Disamping itu untun BBCA, BBRI dan BBNI telah eksis selama 5 tahun berjalan masuk indeks pasar modal paling likuid dan memegang kapitalisasi pasar terbesar di LQ45 selama 5 tahun. Sedangkan MAYA dan BNLI tidak pernah masuk indeks 45 perusahaan yang disarankan oleh bursa efek.

\section{Teknik analisis data}

Untuk mengetahui apakah industri perbankan berkinerja secara rata-rata keseluruhan dan mengetahui apakah industri perbankan layak menjadi pilihan yang tepat untuk investor mengunakan analisis:

1. Rasio likuiditas ROA - ROE tingkat menghasilkan laba dari Asset dan modal

2. Current Adequaacy Ratio (CAR) Rasio Kecakupan modal yang berfungsi menampung risiko kerugian yang kemungkinan dihadapi oleh bank

3. Kebijakan Perusahaan (DPR) seberapa besar persentase deviden yang dibagikan kepada para investor

4. Analisis Sekuritis Equitas

1) Earnings Pershare (EPS) ekspektasi laba perlembar saham yang didapat

2) Price Earnings (PE) Perbandingan harga saham dari modal

3) Price To book value (PBV) Perbandimgan harga saham dari nilai buku aslinya

4) Dividen Yield ekspektasi keuntungan perlembar deviden yang didapat.

5. Distress prediction (X-Score)

Dianalisis dari ke 5 perusahaan dari sampel selama 5 tahun berjalan dari periode 20132017. 


\section{HASIL DAN PEMBAHASAN}

Tabel 2. Rata-rata industri Perbankan Secara Keseluruhan

\begin{tabular}{ccccccccc}
\hline \multicolumn{7}{c}{ Kinerja Rata-rata Bank BBCA-BBRI-BBNI-MAYA-BNLI } \\
\hline No & Year & ROA & ROE & CAR & DPR & DY & EPS & Distress(X-Score \\
\hline 1 & 2013 & $2,57 \%$ & $17 \%$ & $13,46 \%$ & $20,13 \%$ & $7,10 \%$ & Rp364 & -8.23 \\
2 & 2014 & $2,22 \%$ & $19 \%$ & $15,22 \%$ & $16,57 \%$ & $4,87 \%$ & Rp438 & -7.84 \\
3 & 2015 & $2,13 \%$ & $13 \%$ & $16,24 \%$ & $14,67 \%$ & $6,89 \%$ & Rp395 & -7.79 \\
4 & 2016 & $1,24 \%$ & $4 \%$ & $17,97 \%$ & $12,05 \%$ & $4,73 \%$ & Rp395 & -5.59 \\
5 & 2017 & $2,20 \%$ & $10 \%$ & $19,34 \%$ & $18,76 \%$ & $4,59 \%$ & Rp490 & -7.99 \\
\hline
\end{tabular}

*) sumber data di olah 2020

Tabel 2 menujukkan bahwa kinerja perbankan semakin meningkat secara likuiditas tabel diatas dapat digambarkan secara rata-rata industri kemampuan perussahaan menghasilkan laba dari asset cukup baik karena dari nilai rata-rata semua berada diatas $1.24 \%$ dilihat dari ketentuan peraturan BI terkait tentang earnings terkait returns on asset yaitu 1,24\% yang mana berarti secara keseluruhan industri perbankan cukup mampu mengelola assetnya dan menghasilkan laba dari assetnya.

Dilihat dari rata-rata industri dari segi permodalan selama 5 tahun memperlihatkan kondisi yang terus meningkat secara grafik menunjukkan posisi uptren ini menandakan kinerja industri perbankan dari segi permodolan terus membaik segi prmodalan, dan nilai juga meningkat yang dimana nilai minimal bank dikatakan sehat adalah $>=8 \%$ dari keseluruhan nilai berada diatas $8 \%$ dan terus meningkat setiap tahun dari nilai rata-rata 13,46\% di tahun 2013 ke 19,34\% di tahun 2017.

Dilihat dari segi deviden pay out ratio secara rata-rata industri perbankan menghasilkan nilai yang cukup besar tetapi dengan persentase yang cukup menurut yaitu dari 100\% laba selama 5 tahun dibayar kepemegang saham sebesar 20.13\%-18.76 $\%$ dan dari segi Deviden Yield keuntungan deviden perlembar saham cukup menurun berada di level 7,10\%-4,59\%. Dari sisi capital gain cukup memberikan return yang semakin meningkat tiap tahunya yaitu sebesar Rp.364 hingga Rp.490 selama 5 tahun dan selama 5 tahun berjalan industri perbankan tidak pernah mengalami tingkat distress.

Tabel 2. Segi Likuiditas Perperusahaan Rata-rata 5 tahun 2013-2017

\begin{tabular}{llll} 
Bank & ROA & ROE & Rank \\
\hline
\end{tabular}




\begin{tabular}{lccl}
\hline BBCA & $3,77 \%$ & $20,07 \%$ & 1 \\
BBRI & $3,73 \%$ & $21,88 \%$ & 2 \\
BBNI & $2,10 \%$ & $18,88 \%$ & 3 \\
MAYA & $1,14 \%$ & $1,81 \%$ & 4 \\
BNLI & $0,39 \%$ & $-0,60 \%$ & 5 \\
\hline
\end{tabular}

*) sumber data di olah 2020

Tabel 3. Segi Permodalan Perperusahaan Rata-rata 5 tahun 2013 -2017

\begin{tabular}{lrr}
\hline \multicolumn{1}{c}{ Bank } & CAR & Rank \\
\hline BBCA & $20,46 \%$ & 1 \\
BBRI & $19,08 \%$ & 2 \\
BBNI & $11,73 \%$ & 3 \\
MAYA & $13,20 \%$ & 4 \\
BNLI & $11,73 \%$ & 5 \\
\hline
\end{tabular}

*) sumber data di olah 2020

Pengelolaan modal terbaik dinobatkan pada bank BBCA bank ini mampu meminimalisir resiko modal yang tinggi dan mampu mengelola modal untuk profitabilitas dengan baik, disusul oleh bank BBRI

Tabel 4. Segi Instrumen Investasi Fundamental Perperusahaan Rata-rata 5 Tahun 2013-2017

\begin{tabular}{lcccc}
\hline Bank & DPR & DY & EPS & Rank \\
\hline BBRI & $24 \%$ & $11,15 \%$ & Rp721 & 1 \\
BBCA & $24 \%$ & $10,33 \%$ & Rp606 & 2 \\
BBNI & $28 \%$ & $5,20 \%$ & Rp576 & 3 \\
MAYA & $4 \%$ & $1,27 \%$ & Rp170 & 4 \\
BNLI & $2 \%$ & $0,23 \%$ & Rp8 & 5 \\
\hline
\end{tabular}

*) sumber data di olah 2020

Dari segi analisis investasi secara jangka panjang BBRI sedikit lebih unggu dari BBCA jadi untuk analisis keputusan investasi jangka panjang diaraih oleh bank BBRI karena dengan nilai gain dan total persentase deviden yang cukup besar untuk BBNI memang persentase pembangian laba nya cukup besar tetapi orientasi keuntungan persaham nya terteinggal jauh dari ban BRI dan BCA.

Tabel 5. Segi Instrumen Investasi Fundamental

Perperusahaan Rata-rata 5 Tahun 2013-2017

\begin{tabular}{cccc}
\hline Bank & PBV & PE & Rank \\
\hline BBRI & 5,42 & 3,19 & 1
\end{tabular}




\begin{tabular}{lccc} 
BBNI & 4,90 & 10,30 & 2 \\
MAYA & 5,00 & 13,03 & 3 \\
BNLI & 7,90 & 16,72 & 4 \\
BBCA & 6,83 & 23,86 & 5 \\
\hline *) sumber data di olah 2020
\end{tabular}

Dari harga saham perbandingan laba dana nilai ekuitas perusahaan dengan harga saham termurah di pegang oleh bank BBRI karena nilai PBV dan PE nya kecil jadi harga sahamnya cendrung lebih murah.

\section{KESIMPULAN}

Dilihat dari pembahasan selama 5 tahun berjalan dari tahun 2013-2017 secara rata-rata industri perbankan mampu menunjukkan peningkatan perlahan tapi pasti, baik dari segi likuiditas maupun sisi fundamental yang dimana berarti setiap tahun industri secara jangka panjang mampu menunjukan kinerja yang terus membaik, pada akhir tahun 2017 tidak mencerminkan penurunan tetapi mencerminkan peningkatan dari tahun sebelumnya 2016, sehingga sektor perbankan memiliki pilar yang kuat untuk tetap kokoh dari segi fundamental dan tahun depan akan tetap dalam kondisi yang cukup profitble.Dari hasil walupun tidak semua bank memberikan kinerja dengan baik seperti bank Maybank dan BNLI dipenghujung tahun menunjukkan tingkat riturning yaitu tingkat yang memberi harapan perusahaan bangkit dari masa sadways maupun downtren ke dua perusahaan ini tidak memiliki pengaruh besar terhadap industri sektor perbankan, tiga perusahaan BBCA,BBRI dan BBNI sudah lebih dari cukup mampu untuk menggambarkan kinerja perbankan dalam kondisi yang cukup prima.

Walaupun pertengahan tahun 2018 nilai rupiah mengalami melemah cukup parah ditambah dengan tingkat inflasi yang semakin tinggi yang menyebabkan penurunan drastis indeks harga saham gabungan dengan fundamental yang kuat sektor perbankan tidak akan mengalami perubahan dari ke sisi grafik yang downtren dari fundamental selama 5 tahun sudah cukup membuktikan bahwa dengan fundamental perusahaan yang baik, perusahaan akan mampu bertahan di kondisi itu.

Melemahnya nilai rupiah terhadap IHSG terutama harga saham memang berpengaruh dan juga berdampak keharga saham perbankan di pertengahan tahun tetapi dengan fundamental yang baik penurunan harga saham hanya akan terjadi sementara saja dan akan kembali normal pada saat rupiah kembali menguat karena 
dari segi fundamental perusahaan mampu memprediksi pendapatan yang profiteble diamasa mendatang.

Rekomendasi untuk investor industri perbankan adalah pilihan yang sangat dianjurkan untuk investor karena disamping memberikan gain yang tinggi juga memberikan yield yang tinggi juga setiap tahunnya mengalami peningkatan dan tren yang cukup menjanjikan kedepannya investor akan mendapatkan retrun yang lebih dari modal yang dikeluarkannya, untuk kondisi ekonomi yang memburuk seperti melemahnya harga rupiah dan penurunan harga saham bukan berarti investor harus menjual saham yang dimilikinya karena dari segi fundamental kedepannya akan kembali membaik, atau memilih tidak berinvestasi karena hal itu adalah juga salah satu kesempatan jika orientasi investor pada jangka panjang maka saat nilai harga jual saham itu turun adalah kesempatan bagi investor membeli harga saham disaat kondisi nya sedang murah atau disebut dengan Buy On Weakness jadi untuk perusahaan perbankan pelemahan nilai rupiah tidak terlalu berpengaruh justru moment itu bisa dijadikan kesempatan untuk investor berinvestasi.

Selama 5 tahun berjalan dari 2013-2017 disektor perbankan terus menunjukkan kemampuan nya untuk mensejahterakan para investor dapat dilihat dari keuntungan perlembar saham atau EPS yang dihasil kan terus meningkat dan perbandingan harga pasar saham dibandingkan dengan harga nilai buku aslinya semakin menurun ini menandakan harganya sahamnya menjadi semakin murah, dan dilihat dari retrun dividen walupun menurun masih tergolong hitungan menguntungkan karena persentase nya masih tergolong cukup tinggi di 7\%-4\% dari sisi dividen yield yang dihasilkan. Untuk saran keputusan investasi bagi investor karena investor mengharapkan Retrun dan Capital Gain keputusan terbaik ada perusahaan Bank Rakyat indonesia dan Bank Negara indonesia dilihat dari Earning pershare atau keuntungan yang dihasilkan cukup konsisten mengalami peningkatan dan disamping gain yang terus meningkat harga sahamnya cendrung semakin murah jika dilihat dari nilai ekuitas aslinya dan masih tergolong masih cukup memberikan keuntungan dividen. Untuk perusahaan Bank Central Asia kinerjanya juga cukup baik tetapi harga sahamnya masih tergolong jauh lebih mahal di bandingkan Perusahaan Bank Rakyat indonesia dan Bank Negara Indonesia dari ke tiga perusahaan ini dinilai mampu mensejahterakan investor yang berinvestasi.

Saran untuk penelitian selanjutnya untuk lebih menambah jumlah sample sehingga hasil penelitian lebih relavan untuk digunakan karena masih ada bank yang memberikan banyak pengaruh baik positif maupun negatif di industri perbankan, 
selanjutnya menambah periode berjalan untuk tahun kinerja bank saat pendemi saat ini.

\section{REFERENSI}

Aprayuda, R., \& Misra, F. (2020). Faktor-faktor yang Mempengaruhi Keinginan Investasi Investor Muda di Pasar Modal Indonesia, E-Jurnal Akuntansi Universitas Udayana, 30(5), 1084-1098.

Alrgaibat, G. A. (2016). Financial and Economical Analysis of Banking Activities: Case Study of Jordan. International Journal of Academic Research in Accounting, Finance and Management Sciences,6(4), 90-101. "Data kapitalisasi pasar 2018" https://ojk.go.id/id/kanal/perbankan/berita-dan-kegiatan/siaran-pers

Fahmi, I. (2014). Manajemen Keuangan Perusahaan dan Pasar modal. Jakarta: Mitra Wacana Media.

Handayani, T., \& Abubakar, L. (2017). Perkembangan Hukum Sektor Jasa Keuangan Dalam Upaya Percepatan Pertumbuhan Ekonomi Nasional. DE LEGA LATA: Jurnal Ilmu Hukum, 2(2), 418-444.

Hidayat, R. (2010). Keputusan Investasi Dan Financial Constraints: Studi Empiris Pada Bursa Efek Indonesia. Buletin Ekonomi Moneter dan Perbankan, 12(4), 457-479.

Husni, T., Rahim, R., \& Aprayuda, R. (2019). Cash Compensation, Corporate Governance, Ownership, and Dividend Policy on Banking Performance. In 6th Annual International Conference on Management Research (AICMaR 2019), Advances in Economics, Business and Management Research,132 (pp-212-218). Atlantis Press.

Koesrindartoto, D. P., Aaron, A., Yusgiantoro, I., \& Dharma, W. A. (2020). Research in International Business and Finance Who moves the stock market in an emerging country - Institutional or retail investors ? Research in International Business and Finance, 51(1), 1-28. https://doi.org/10.1016/j.ribaf.2019.101061

Liwe, C. T., Tommy, P., \& Maramis, J. B. (2018). Reaksi Investor dalam Pasar Modal atas Peristiwa Menguatnya Kurs Dolar Amerika Serikat terhadap Nilai Tukar Rupiah pada 26 Agustus 2015 (Study pada Perusahaan Manufaktur Sub Sektor Food and Beverage yang Listed Di Bei). Jurnal EMBA: Jurnal Riset Ekonomi, Manajemen, Bisnis dan Akuntansi,6(3). "Pertumbuhan SID 2012- 2017" wwww.ksei.co.id/ investor/pasar/modal/tembus/1/juta/20170608191649

Solihat, A. N., \& Arnasik, S. (2018). Pengaruh Literasi Ekonomi Terhadap Perilaku Konsumtif Mahasiswa Jurusan Pendidikan Ekonomi Universitas Siliwangi. Jurnal Kajian Pendidikan Ekonomi Dan Ilmu Ekonom, 2(1), 1-13. 
Sofyan, R., Putra, D. G., \& Aprayuda, R. (2020, November). Does the Information on the Internet Media Respond to the Stock Market?. In The Fifth Padang International Conference On Economics Education, Economics, Business and Management, Accounting and Entrepreneurship (PICEEBA-5 2020), Advances in Economics, Business and Management Research,152 (pp. 510-520). Atlantis Press.

Untung, B. (2011). Hukum Bisnis Pasar Modal. Yogyakarta: Andi.

Veno, A., \& Syamsudin, S. (2016). Analisis Trend Kinerja Keuangan Perbankan Syariah Tahun 2015 Sampai Dengan 2017. BISNIS: Jurnal Bisnis dan Manajemen Islam, 4(1), 21-34. 